\title{
Exploring Ways of Vocabulary Instructional Practices in ESL Classrooms in Pakistan
}

\author{
Rifa Anjum \\ M.S Scholar (Applied Linguistics) at English Language Development Centre \\ Mehran University of Engineering \& Technology, Jamshoro, Pakistan \\ Shumaila Aijaz Memon \\ Associate professor at English Language Development Centre \\ Mehran University of Engineering \& Technology, Jamshoro, Pakistan
}

\begin{abstract}
Word Power offers a key role when it comes to effective communication and comprehensive reading. Language teaching-learning is a complex phenomenon especially in learning L2 vocabulary. A learner is provided with a complete package of textual and non-textual language-based content to develop all four skills of L2 of a learner. A language curriculum is based on text aided by co-curricular activities like role plays, presentations, speeches/debates or declamation, essay writing competitions, etc. to improve the language proficiency of a learner. In such activities, vocabulary has a secondary role to play, whereas, it is hard to find such activities where the prime focus is to be given on the development of language learner's vocabulary size. Language learners view vocabulary enhancement as one of the most challenging domains while learning a language Çelik \& Toptaş, (2010). The present study reflects a brief overview of the most frequently practiced pedagogical practices of vocabulary items. This study is qualitative, where secondary level school learners are the target population. The researcher has chosen semi-structured interviews with students $(n=20)$. The study finds that the vocabulary instructional process in Pakistani ESL learners lacks the proper induction of vocabulary teaching strategies. It doesn't target the utilization of vocabulary items in a meaningful context. In addition, vocabulary items are heavily taught explicitly and implicit instructional methods are not taken much into consideration. Thus, the researcher recommends the integration of best teaching practices into the traditional language pedagogical process. It may involve CALL methods and other incidental and intentional approaches that can enable learners to enhance vocabulary size, retain, and use vocabulary items in a real-life context.
\end{abstract}

Keywords: Vocabulary teaching/learning, ESL learners, CALL, traditional practices, pedagogical practices, vocabulary development, language learners

DOI: $10.7176 /$ RHSS/10-24-09

Publication date: December $31^{\text {st }} 2020$

\section{Introduction}

English has become an indispensable part of human lives providing global dominance and significance in every domain of life including educational domains. Similarly, in the Pakistani education system, English is being taught as a compulsory subject up to the higher education level. Pathan (2012), mentions that "English is taught as a subject at School, College, University, and Madrassa (religious school) level in Pakistan." Though the learners have encountered English since the initial stages of education even then they find themselves incapable to produce meaningful utterances in a real-life context. Despite an asserted focus on teaching/ learning English since the early years, most students do not have the necessary command in English language skills to communicate proficiently because they lack word power. "The language learners still face difficulties in almost every area: reading, writing, listening, speaking, vocabulary, grammar...” Dar \& Khan (2015). Keeping this background in focus, the current study centered around pedagogical practices of Vocabulary at the Secondary level in an Elite private school (EPS) in Hyderabad.

Vocabulary development is a pre-requisite while learning second language. Learners with a large stockpile of words find themselves more confident and proficient as compared to the students with limited word power. For this purpose, effective instructional strategies are required. Sedita (2005) emphasizes upon following effective vocabulary instructional strategies across all grade levels to bridge the existing gap in learners' vocabulary size. Due to this, this phenomenon needs investigation that what are the ways through which vocabulary is being taught. Stahl (2005), puts forward his view that,

"Vocabulary knowledge is knowledge; the knowledge of a word not only implies a definition but also implies how that word fits into the world." Studies have shown that word power empowers the growth of reading competency and promotes better understanding. Learners with less vocabulary scores have low comprehension; Whereas, students with better vocabulary scores have better comprehension. McCarthy, O'Keeffe, and Walsh (2010) believe that the effectiveness of language is directly proportional to the word knowledge, in which not only accurate word pronunciation of the word but also its production is included. Likewise, Read (2000) 
highlighted the role of vocabulary learning, by calling words, "a basic building block of language". Sedita (2005) asserts that Vocabulary knowledge plays an immensely significant role in effective communication of ideas. Therefore, Vocabulary instruction is a crucial component of language acquisition because it has got a major role to play in receptive and expressive literacy.

\section{Literature Review}

Vocabulary, in some ways, is one of the most prominent and significant dimensions of language that learners need to master. It is considered helpful due to the importance of meaning i.e. both in learning and understanding English as a second language (ESL). On the contrary, learners' opportunities for the exposure of word items and their approaches towards vocabulary acquisition have highly been neglected in the ESL classroom. Watkins, (2007) states that learners can be enabled to get a good command of language skills in case they are provided sufficient exposure to vocabulary development activities.

English teaching has been becoming an overwhelming phenomenon in recent times. Whenever we talk about the teaching of English as either a second or foreign ESL OR EFL language then, we mean to talk about the teaching of listening, speaking, reading, writing, grammar, pronunciation, etc. individually. Pakistan, being a multilingual state has been facing barriers on various levels. These are linguistic, psychological, and more importantly pedagogical barriers. However, English teachers face a lot of challenges while battling against these barriers, which include lack of pre and in-service training, lack of awareness or reach to digital means, the teaching of English as a subject, and pressure to cope up with syllabus content. Resultantly, the English curriculum contains more exercises and activities of listening and reading, writing, speaking and grammar, the emphasis on vocabulary instruction is very rare.

\subsection{Significance of Vocabulary Instruction}

Vocabulary instruction is of prime importance for language learners as without enough words learners can neither express themselves nor they can understand others. "Lexus is the origin or heart of the language". Lewis (1993). Therefore, language learners often readily discern the significance of words in learning their language. "Learners carry dictionaries, not grammar books" Schmitt (2010). In short, teaching words enable learners to understand and make conversation with others in English. "It's very difficult to put language into words," Voltaire said bluntly. According to his beliefs English language students are usually brief, but still learning vocabulary allows learners to learn English for their purposes.

\subsection{What is Vocabulary?}

Quoting the often-cited quote of David Wilkins, (1972) "without grammar very little can be conveyed, without vocabulary, nothing can be conveyed" would be worthy to explain the attention required by vocabulary as a fundamental language entity. Due to its multifaceted role and place in language learning, it still seems undecided phenomenon for researchers to define the term "Vocabulary". What is vocabulary? What does it mean by knowing a word? These questions seem very simple hence complicated at the same time to answer. Hence, it's not quite easy to arrive at a unanimous definition of what is the meaning of knowing a word and what is a vocabulary.

Nation (2010), states that "knowing a word" (Word knowledge) refers to the ability to perceive the written and spoken form of the word along with the meaning of the given word, which means that knowing a word is a two-step process.

Firstly, being able to conceive it or recognize it (receptive) and secondly, being able to use it (productive). Although this definition appears to simplify the entire concept of "Knowing a word", on the contrary, it has presented a vague picture of the concept that what is word knowledge The reasons are it doesn't talk about the other aspects of the target language attach to the word. It doesn't refer to the link between a form of the word along with the meaning. Furthermore, knowing any vocabulary item is not about only knowing the mere association of words' meaning and their form. Laufer \& Goldstein, (2004). In short, every language researcher seems to come forward with his definition of vocabulary, concerning its role in language and the conveying of meaning. Hence, it is somehow challenging to proposed a unanimous definition of "vocabulary" due to its multifaceted capacity. However, it is clear that vocabulary is a list/collection of words but there is no complete and exhaustive research or theory that how vocabulary is learned. According to Nation (2001), knowing a word includes three steps, knowing of form, knowing of meaning, and knowledge of use. Figure I elaborates it in detail.

As mentioned in the fig I, knowing a word involves three aspects, form, meaning, and usage with various embedded components in it. Whereas, Nations clearly divides word knowledge into two categories i.e. receptive and productive. Hence, it is another debatable issue that which category would be preferred or how both categories would be addressed in a balanced way.

On the other hand, there comes a question of word teaching and learning, which learning strategy should be implied. Rubén Chacón-Beltrán et al. (2010) assert that researchers are struggling to come up with a model of 
vocabulary learning in L2 but do not hold any success so far, "to provide a theory or model that can explain vocabulary learning ... it will require the coordinated work of linguists, SLA [second language acquisition] researchers, psychologists, and neurobiologists". (pg. 2).

\subsection{Incidental v/ Intentional Vocabulary Instruction}

There exist two possibilities for processing vocabulary instruction. These are incidental or implicit and intentional or explicit instruction. The unconscious acquisition of vocabulary items, where the learner is unaware of their acquired vocabulary items is referred to as incidental learning, which is a behaviorist approach of vocabulary instruction. Ellis (1994) states,

"An implicit vocabulary learning hypothesis holds that the meaning of a new word is acquired unconsciously as a result of abstraction from repeated exposures in a range of contexts"....

Therefore, the process of vocabulary acquisition is termed "incidental learning". Rubén Chacón-Beltrán et al, (2010). Krashen (1989) is of the view that language is learned subconsciously. At the time learners are acquiring it, their attention is on the message rather than on the word form, hence, they are unaware of the acquisition of it, this is what Chomsky has referred to it as "tacit knowledge". In the same regard, Demir (2013) cited, "In vocabulary acquisition, incidental learning is broadly defined as the learning of vocabulary as a by-product of any activity not explicitly geared towards vocabulary learning” Rieder, (2003).

On the contrary, conscious attention is implied to the acquisition of new words and their meanings. Here the learner is fully aware of the vocabulary gain and this process is referred to as Explicit or Intentional learning. Ahmed's study (2012) confirms that the more suitable strategy for vocabulary learning would be incidental learning strategy than the intentional method of vocabulary instruction because "intentional vocabulary items are more prone to cramming rather than involving learners' cognitive process of learning". In short, children with impoverished vocabulary knowledge do not catch up with their fellow learners under normal classroom instruction unless a strong vocabulary emphasis is added.

To put it in a nutshell, an intentional strategy for vocabulary learning is defined as an activity of retaining lexical knowledge to memory. Whereas, Nation (2001) argues that, " inferring vocabulary meaning from context ... is an essential strategy for developing reading comprehension and promoting lexical acquisition".

It is considered effective to follow a model or design a framework before imparting vocabulary knowledge. A language instructor must know the essential components of effective vocabulary instruction. "There may also be an advantage of applying metacognitive strategies to remember new vocabulary to consolidate a new understanding by repetition." Following the adapted image (See fig II) of Grave (2006) is taken from Susan Hanson et al, (2011).

This model illustrates the essential components that need to be considered while designing any vocabulary lesson plan from drafting word learning teaching strategies to executing the plan to foster vocabulary enhancement. Each step involves meticulous consideration of multiple ways that can help nurture the growth of word knowledge among learners. However, this is one of the many instances that may be considered by language teachers to contemplate such models before outlining a detailed vocabulary lesson plan. It would bring a better understanding of the instructional process for the teacher and efficacy in the entire learning process.

The aforementioned, Literature review helps the researcher identify formulating the following research objectives for the study.

\subsection{Research Objectives}

The study at hand aims to achieve the following objectives at the end of the research:

- It aims to explore the pedagogical practices concerning vocabulary instruction in Pakistani ESL classrooms of Elite class Private schools at the secondary level.

- It attempts to explore the efficacy of existing vocabulary practices in ESL classrooms.

- It further aims to suggest (if required) how these strategies can be made more effective for a better learning outcome.

\subsection{Research Questions}

This study addresses one broader and two sub-questions to answer: Following is the main RQs followed by probes of the same question:

Q1. What are the ways secondary school learners have been learning vocabulary at a private school in Pakistan?

Probe: 1: How far learners are content with the efficacy of current vocabulary practices in ESL classrooms?

Probe: 2: What are the ways through which vocabulary practices can be made more effective in ESL classrooms? 


\section{Methodology}

To collect the data for the present research, semi-structured interviews were conducted with participants. Qualitative research benefits the researcher in accessing a wide range of data. Cropley (2019) asserts that,

"The task of qualitative research is to gain insights into these constructions of reality, i.e., to tease out the nature of the world as it is experienced, structured and interpreted by people in the course of their everyday lives."

Moreover, semi-structured interviews have been used to collect the data. Interviews provide the researcher to gain a profound and detailed understanding of existing practices or phenomena experienced by participants. It also explores the way participants making out meanings from their experiences in their daily lives. Therefore, the Interview protocol used was adapted from Nazir, (2017) depending on the similar research context.

\subsection{Population and Sampling}

The research site of this study is an Elite private school, (EPS hereafter) where the researcher herself has been teaching for the last 05 years. The interviews were conducted with EPS secondary level learners. A convenient method of sampling has been used by the researcher for this small-scale study. Convenience sampling is also known as Haphazard Sampling or Accidental Sampling. It is a type of non-probability or non-random sampling where participants of the target population are sorted on the criterion of proximity. It includes accessibility, willingness to participate, or availability at a given time, which are required for the study. Dörnyei, (2007)

In addition, ethical approval for the study procedures was obtained from the school management. The real name of the school will be hidden for the sake of reputation. All participants of EPS provided written informed consent, by signature.

\subsection{Procedure}

Medium of communication deliberately designed to be flexible so that the true picture of the phenomenon can be obtained. Each interview lasted for 45 minutes. There were 20 students of EPS i.e. both genders, but they were taught by different teachers. All of them are secondary school learners. All interviews were audio-recorded and notes were also taken. Transcripts of interviews were analyzed in accordance with the dimensions of the interview. The qualitative data collected for this study through interviews i.e. semi-structured interviews, which are analyzed by using Constant Comparative analysis. In this method, themes are generated after coding and filtration through the "feel like" and "look like" criteria. The interview protocol has been designed to explore pedagogical practices during the vocabulary instructional process. It is targeted at the students to investigate whether they're satisfied with their classroom practices if not then what are the changes (if any) that should be offered to them for learning vocabulary in the place of existing teaching practices. This data ascertains the depth of traditional teaching practices and learners' readiness to integrate some motivational, exciting, and cognitive building resources and strategies to make vocabulary instructional practices effective.

\section{Results}

The results of the study are presented in a thematic pattern to present it in a coherent and intelligible way for the readers. Following patterns emerged from the current study.

\subsubsection{LEXICON IS THE HEART OF LANGUAGE LEARNING}

The vocabulary teaching/learning process lies at the heart of language learning. Although, it is a complex phenomenon to explain this study examines the depth of the existing practices of vocabulary acquisition. As Hunt and Beglar believe that "the heart of language comprehension and use is, the lexicon" (2005), Teaching and learning of vocabulary items are immensely influenced the way vocabulary knowledge is perceived. Therefore, the study confirms the fact that vocabulary is a complex phenomenon in L2 learning as participants strongly believed that they lack expression and understanding unless they armed themselves with the word power. Hence, the meaning of "vocabulary" implied by learners refers to the word knowledge with its meaning in multiple contexts because the dictionary definition of the word restricts them from using it freely like a language learner. This process involves repeated exposures which influence the retention of the word in the learner's language knowledge. Learners don't see vocabulary knowledge as mere retention of a word list along with its specific meaning. According to them, if a learner does so, then he/she will always be failing in recognizing the real essence of gaining vocabulary knowledge.

\subsubsection{TRADITIONAL VOCABULARY INSTRUCTIONAL PROCESS:}

The findings of the study explore current pedagogical practices as ineffective, insufficient, and unfathomable in many ways. Firstly, the current vocabulary teaching practices involves transmitting of vocabulary item confined to book's content as English is taught as "subject" rather than a "language". The majority of participants agree that they study content-related things more in the classroom than vocabulary, which is why they have the less developed vocabulary. Secondly, the transmission includes lexical items with its given meaning with no or very limited opportunity to use it in a relevant context. Thirdly, excessive communication of vocabulary knowledge relies on 
the direct method which centers on dictation, finding out meaning in the dictionary, explaining words through readout aloud strategy, providing a word bank or list of synonyms including rote learning. On the other hand, the majority appreciated the synonym-based strategy above all other strategies used by their ESL teachers in the classroom. A participant showed willingness towards synonym based vocabulary learning as per the following:

"Our teacher asks us to find out the meaning of new words or sometimes their synonyms from the dictionary" 4.1.3 INOPERABLE VOCABULARY ACTIVITIES

Learning has greatly evolved over the years, even in Pakistan. The traditional class involves face to face instructional learning. In ESL classrooms, in Pakistan, still, lessons and classes have traditional execution where most of the time teacher is the authority to serve the learning goals.

Although, there are participants who confessed that their teacher tries to engage them in activities that help learners using learned vocabulary in multiple contexts, such as role-plays. Moreover, learners also expressed their views that they are not satisfied with the pedagogical ways and amount of time allotted to vocabulary practice in the classroom. Besides, the lack of frequent usage of motivational strategies, separate vocabulary lessons, activities, or competitions has been practiced for vocabulary development and enhancement. In addition, technological aids and other resources for vocabulary teaching are rarely highlighted and the case is not similar to all ESL classrooms. Participant 10 stated,

"Once in a blue moon, we are provided a chance to have any physical activity inside the classroom where, we are asked to use targeted words."

\subsubsection{UNSATISFACTORY AND UNPLANNED LEARNER'S AUTONOMY}

The results suggest that learners are quite displeased with the typical traditional ways of teaching/ learning vocabulary. They don't find a vigorous impact of these instructional ways on their receptive and productive vocabulary. Although most of the learners like synonym's strategy again they had said its usage is not practiced in a way it should be using multiple language contexts.

Further, some learners indicated that they believe they would not excel in the field of receptive and productive literacy development if they'll rely on classroom instructions, and hence, they take the driving wheel into their own hands and started engaging themselves in activities that aid vocabulary development. Such activities involve watching YouTube videos targeting vocabulary building, games on a website that help in retention along with developing an understanding of the word in its different meaningful context.

\subsubsection{INTEGRATION OF DIGITAL PRACTICES}

Hence, Pakistani ESL classrooms lacking digital resources, and students find this factor encouraging to revive and update existing practices which has made the vocabulary development process lifeless, monotonous, and barely enduring. All participants strongly agreed that their teachers should work on making vocabulary practice more engaging by using technological sources to get a better learning outcome.

"It should be more exciting and engaging for us to learn vocabulary from social media. It would provide more opportunities to use its meaning in a variety of contexts. For example, for me learning through song, movies, and other internet websites work more than learning vocabulary in the classroom. It fascinates me more than boring drilling practice or tiring attempts of retention."

Participant: 14

\subsection{Discussion:}

Undoubtedly, word learning is a complicated process that deserves attention. The results drawn from this study reflects a need of change in pedagogical practices in Pakistani ESL classroom, not because they are entirely failing but because they are no more influential and rigorous vocabulary instructional plan to stimulate learners for the vocabulary building process. According to the study, learners find it a supremely important aspect of their language. They believe that robust vocabulary provides a foundation to them in clear expression be it receptive or productive domain i.e. listening and reading or speaking or writing. Moreover, incapacitated vocabulary hinders their growth in receptive and productive language proficiency. This is what Nation (1990) claims that "Learners feel that many of their difficulties in both receptive and productive language use result from an inadequate vocabulary"

For several decades, vocabulary has been viewed as the teaching of word cards and word lists and teachers assumed that through memorization of words learners will be enabled to achieve their proficiency and other linguistic goals without providing them extended and exhaustive guidance. Unfortunately, more or less the same techniques are still aligned in ESL Pakistani classrooms. The classrooms are teacher-centered and the learners are taught words directly. This finding seems to be in line with Dayan \& Bano, (2018) study that $72 \%$ of teachers in Pakistan teach using traditional teaching methods involving lecture and dictation strategies. They do not use activity-based techniques that's why classrooms are no more interactive. Therefore, this study has confirmed that vocabulary instruction in Pakistani ESL classrooms heavily relies on direct/ explicit instructional way which is also known as the traditional teaching style. It depends on an authoritative teaching strategy in which a teacher teaches through lecture oriented or self-conducted demonstrations. Specifically, if this is seen in the context of vocabulary instructional practices then through traditional or explicit instructional strategy learners learn words 
via decontextualized vocabulary instruction. As far as selection of explicit teaching technique is concerned then Rubén Chacón-Beltrán et al, (2010) mentions the explicit process of L2 vocabulary learning is useful as, "there is some benefit to vocabulary acquisition from the learner noticing novel vocabulary, selectively attending to it, and using a variety of strategies to try and try to infer its meaning from the context". Reynor (2015) cited Vadasy \& Nelson, (2012). Whereas, Barcroft (2009), acclaimed,

"intentional learning positively affected L2 word-form learning during reading as compared with instructing learners to read for meaning only."

Hence, instructors should realize that some vocabulary items can be taught using incidental methods of vocabulary teaching "without dedicating too much attention to them" Karami, (2019); some explicitly/intentionally, while some of them using a variety of strategies driven from both strategies i.e. incidental and intentional vocabulary strategies. The results of the aforementioned studies throw light upon the similar fact that effective vocabulary instructional ways may vary according to the context of learners and choice of words in ESL settings because relying solely on one single strategy is failing to prove its efficacy in terms of students' performance and their attitude towards vocabulary enhancement. Besides, teachers should be more responsive to new challenges and changes by altering activities and by creating tailored lessons, exercises, and activities for their learners. Similar pattern is observed in the study of (Choo et al., 2012) who have cited various studies by different researchers such as, (Brown, Waring and Donkaewbua, 2008; Laufer, 2005; Read, 2004; Nation, 2001) claiming the integration of both i.e. incidental and intentional strategies. It states, "Incidental vocabulary learning is not necessarily more effective than intentional learning, nor is intentional vocabulary learning necessarily more effective than incidental learning". Resultantly, both the explicit and the implicit strategies should be incorporated into the teaching and learning of vocabulary. Moreover, this study can be helpful for instructors to realize that they shouldn't restrict their classrooms to any particular method or strategy neither to focus on any particular aspect of the word. Hence, a combination of both explicit and implicit strategies would surely help students and their instructors to consider all aspects of vocabulary including form, meaning, collocation, register, and many more. This finding is quite similar to Nation's (1990) opinion, which he established at the beginning of his book that a teacher must diligently choose or rejects a strategy based upon a deep understanding of the way vocabulary should be dealt with, its teaching principles along with considering its theoretical and experimental justification. Dictionary strategies are seen by few learners $(20 \%)$ as an outdated strategy. They find paper dictionaries now a burden to carry in an era where they can google a word in seconds. This is what suggested by Bakar, et al (2011) that an electronic-dictionary allows learners to enjoy a quick look-up to find out the meaning. Similarly, Noor (2011), concluded that e- dictionaries or online resources are the preferred media of today's learners.

The most functional strategy approved by the learners is learning through synonyms. The same pattern emerged from the study of Webb, (2007) that learning synonyms to develop vocabulary may facilitate the process of vocabulary learning. In a comparative study, his data reveals that scores for words learned with synonyms are significantly higher than those learned without it. In the same regard, Nation's (2001) also mentions that learning a synonym of the prior known word may be more trouble-free than learning a word that is non-synonymous. Further, he referred to the endeavor on behalf of learner needed to learn a word is different for different learners which varies from one word to another.

Another strategy, that is reported by learners though not so frequently practiced but they came across it during their vocabulary lessons is learning vocabulary from contextual clues. In simple words, exploring the meaning of a word by looking at the phrases or words nearby Hartmann \& Blass, (2007) cited in Durai Loyola Innaci \& Sam, (2017). Contextualization helps students to better comprehend the word knowledge in context along with its effective usage in the target language. Various shades of vocabulary items are used in a given context to help to master its meaning if a contextual clue is provided. It is somehow more time consuming as it involves a cognitive process to understand and retain the meaning of vocabulary item in the provided context. According to $20 \%$ of learners, they found it useful but unfortunately they don't devote much time of class to the vocabulary learning process that's why they had often used it. On the contrary, most of the learners find it a bit difficult to derive the meaning out of a context. The same pattern emerged in the study of Nassaji (2004), who concluded that learners "need good vocabulary knowledge to be able to successfully derive word meanings from context." Consequently, students already facing challenges in vocabulary development didn't enjoy it.

However, it is critical to examine the ways/strategies through which intentional vocabulary is being taught. Young-Davy, (2014) suggests three steps to intentional vocabulary teaching, i.e. selection of the words, definition, and exposure, and usage.

On the other hand, the study investigates that modern trends have been neglected and a lack of planning to design activities for the learners is reported. Olijra (2015) study concludes that as compared to other language skills such as listening, speaking, writing, and reading. Vocabulary acquisition has been given less attention in proportion to the attention provided to other language activities. Whereas, using digital resources and technological aid can provide teachers the possibility to offer to refurbish vocabulary lessons and thrilling exercise to master their vocabulary. Instructors might be able to leverage educational time with the aid of having learners work 
independently, both pre or after post texts, since it offers multiple sources and opportunities for teachers and learners to identify words, analyzing structures, understanding various meanings, and discovering those words in some multiple contexts. Language teachers should aim to design independent strategies for vocabulary learning that can make learners stick and engaged in the vocabulary development process. Correspondingly, the latest research by Sivagnanam, \& Yunus (2020) concluded that "the use of social media serves as an interactive tool that helps ESL learners to learn subconsciously. Therefore, computer applications here can be used as a supplement to improvise the traditional teaching and learning method". Though the findings do not refute the traditional practices of vocabulary instructions, yet it demands to make existing pedagogical ways more coherent, more efficient, more thrilling, and more streamlined with digital resources as per the demands of the latest teaching patterns. To put it in a nutshell, teachers need to revise their instructional strategies along with allowing students to make use of their independent resources other than the textbook and enable them to practice those in the classroom.

"An important aspect of developing students' robust vocabularies is teaching them tools to unlock the meaning of unknown words." Antonacci and O’Callaghan, (2012).

Taken together, this phenomenon is happening due to the fact that still English is taught as a subject to learners rather than the language. Therefore, lack of efficacy is one of the shortcomings of this widespread system. The setup in ESL classrooms is not favorable to L2 learning/teaching. There are certain shreds of evidence put forward by Warsi, (2004), it states that "Courses are taught without specific curricular objectives; English language teachers are not equipped with efficient pedagogical tools; most English language teachers rely on obsolete teaching techniques; inappropriate textbooks are chosen to teach English as a Second Language...."

To sum up the findings of the study, ESL classrooms are loaded with the factual aspects of syllabus completion and covering the targeted curriculum. Further, either during the lesson or after the lesson reading some time (minutes) are attributed for explicit teaching of words. Basic explicit vocabulary instructional techniques have been followed which lack the usage of invigorating sources and the entire instructional process revolves around the prescribed text. These include synonyms, word lists, guessing, or looking up a word in the dictionary or glossary provided with the lesson. Likewise, the learners' classes have been designed weekly by keeping, speaking, listening, reading, and writing tasks in view. Each language category has equally been allotted activities. The next session enlists the major findings of the study.

\section{Summary of the Major Findings:}

1. The study portrayed that in proportion to the other four language skills the process of word learning/teaching is less emphasized. In comparison to other language activities, teacher-learner understanding and awareness of the effective teaching strategies are relatively poor.

2. The results of the study also indicated that the majority of the teachers use the direct method of vocabulary teaching whereas, the words are limited to the textual exercises. They continue to practice the role of traditional teachers where they are bound to only transmit word knowledge and later on assess that knowledge.

3. The study supports the idea that learners feel intimidated due to ineffective vocabulary learning and teaching practice and not all but some of them learn vocabulary on their own as they don't feel gruntled the way vocabulary is taught in the classroom.

4. The patterns that emerged in this study relatively highlight the fact that much of the class time is devoted to teaching-learning of factual aspects, therefore, less time and attention is allotted to vocabulary learning.

5. The present study constitutes that there is no integration of technological aid and digital resources to teach vocabulary. On the contrary, learners feel motivated and excited in learning vocabulary from social media websites or other digital resources to develop their vocabulary in the future.

6. The evidence found in the study supports the idea that ineffective vocabulary pedagogical practices resonate with an indifferent attitude towards learning English among learners and they feel it like a burden.

7. This study reveals the fact, confirmed by learners that their teachers are less helpful and motivating in empowering them to improve their vocabulary knowledge. Whereas, it is considered essential to develop learners' autonomy and self-responsibility to enhance their skills. Moreover, students are not given opportunities to practice vocabulary outside the classroom in a different context.

\subsection{Conclusion:}

Vocabulary development is an indispensable and multifunction task for second language learners. It seems that the phenomenon needs to be handled with great concern as it needs a dire need of integration of modern strategies and best practices to bring effectiveness in the pedagogical practices of vocabulary instruction. In light of the results, it is recommended to give digital resources a chance to promote a better comprehension of the lexical competence of secondary ESL learners in an Elite Private school in Hyderabad.

This small-scale study opens up a multiple-fold phenomenon that has deeply rooted in our education system. it has concluded that serious attention and place for teaching-learning vocabulary instruction should be made 
inclusive in curricula. The concept of intentional and accidental approaches to vocabulary should be made more clear to the teacher. Repetition of old activities with no proper integration or advancement should cease to be practiced. Teachers may design and integrate vocabulary development activities in language classes. For instance, narrating stories, activities using cognition, or the transfer of information can be quite beneficial for learners to learn how to use vocabulary items productively.

In short, the pedagogical implications of this small scale study cannot be generalized. In essence, ESL learners need a huge stockpile of words to use and to function meaningfully in a language

\subsection{Proposed Research Implications.}

For the implication, this study advocates that ESL teachers should be trained also that they should not into technological advancement pass by without utilizing it to serve vocabulary teaching grab to be accomplished. More importantly, this study does not refute the traditional practices entirely, that's why further research can be made to investigate vocabulary practices at larger scales addressing more public and private sector schools. The results of this study will also help educationists to integrate digital resources and technological aids in the classroom, since receptive and productive vocabulary development needs various contexts and more communicative tasks to enable a learner in becoming proficient speakers of L2.

\section{References}

$>$ Antonacci, Patricia. and O'Callaghan, Catherine M. (2012). Promoting literacy development: 50 researchbased strategies for K-8 learners. Thousand Oaks, California: Sage Publications. 83-87.

$>\quad$ Bakar, N.A., Noor, N.M., Azman, H.,Nor , F.M.N., \& Hamat, A. (2011). Students evaluation of an intelligent English language literacy system (I-ELLS). The International Journal of Educational and Psychological Assessment.6(2), 63-83.

$>$ Barcroft, J. (2009). Effects of English generation on international L2 vocabulary learning during reading. TESOL, 43 (1), 79-103. https://doi.org/10.1002/j.1545-7249.2009.tb00228.x

$>$ Choo, L. B., Lin, D. T. A., \& Pandian, A. (2012). Language Learning Approaches: A Review of Research on Explicit and Implicit Learning in Vocabulary Acquisition. Procedia - Social and Behavioral Sciences, 55, 852-860. https://doi.org/10.1016/j.sbspro.2012.09.572

> Çelik, S., \& Toptaş, V. (2010). Vocabulary learning strategy use of Turkish EFL learners. Procedia - Social and Behavioral Sciences, 3, 62-71. https://doi.org/10.1016/j.sbspro.2010.07.013

$>$ Cropley, A. J. (2019, 2nd updated, revised, and enlarged edition). Qualitative research methods: A practiceoriented introduction for students of psychology and education. Riga, Latvia: Zinātne. (open access - doi: 10.13140/RG.2.1.3095.6888)

$>\quad$ Dar, M. F., \& Khan, I. (2015). Writing Anxiety among Public and Private Sectors Pakistani Undergraduate University Students. Pakistan Journal of Gender Studies, 10, 157-172.

$>$ Dayan, U., \& Bano, A. (2018). Creating Interactive Classrooms: Barriers for the Teachers in Pakistan. PUTAJ -Humanities and Social Sciences, 25(2). http://journals.uop.edu.pk/papers/07\%20Uzma\%20Dayan.pdf

$>$ Demir, Y. (2013). The Role of In-class Vocabulary Strategies in Vocabulary Retention of Turkish EFL Learners. Elementary Education Online, 19(04). http://citeseerx.ist.psu.edu/messages/downloadsexceeded.html

$>$ Dörnyei, Z. (2007). Research methods in applied linguistics. New York: Oxford University Press.

$>$ Durai Loyola Innaci, \& Sam, P. (2017, September). Using context clues as a vocabulary learning strategy: an experimental study. Research unknown. https://www.researchgate.net/publication/319741383_using_context_clues_as_a_vocabulary_learning_strat egy an experimental study

$>$ Ellis, N. (1994). Vocabulary acquisition: The implicit ins and outs of explicit cognitive mediation. In N. Ellis (Ed.), Implicit and explicit learning of languages (pp. 21 1-282), Academic Press, Harcout Brace \& Company, Publishers.

$>\quad$ Hunt, A. \& Beglar, D. (2005) A framework for developing EFL reading vocabulary. Reading in a Foreign Language, 17 (1), 23-59

$>$ Jameel AHMAD. (2012). Intentional vs. incidental vocabulary learning (Vol. 1). Vol. 1. ELT Research Journal.

> Karami, A. (2019). Implementing audio-visual materials (videos), as an incidental vocabulary learning strategy, in second/foreign language learners' vocabulary development: A current review of the most recent research. i-manager's Journal on English Language Teaching, 9(2), 60-70. https://doi.org/10.26634/jelt.9.2.15519

$>$ Krashen, S.D. (1989). We acquire vocabulary and spelling by reading: Additional evidence for the Input Hypothesis. The Modern Language Journal, 73, 440-464.

$>$ Laufer, B., \& Goldstein, Z. (2004). Testing Vocabulary Knowledge: Size, Strength, and Computer 
Adaptiveness. Language Learning, 54(3), 399-436. https://doi.org/10.1111/j.0023-8333.2004.00260.x

$>$ Lewis, M. (1993). "The lexical approach: The state of ELT and the way forward." Hove, England: Language Teaching Publications.

$>$ McCarthy, M., O'Keeffe, A., \& Walsh, S. (2010). Vocabulary matrix: Understanding, learning, teaching. Hampshire: Cengage Learning.

$>$ Nation, I.S.P., 1990. Teaching and Learning Vocabulary. Boston: Heinle and Heinle Publishers.

$>$ Nation, P. (2001). Learning vocabulary in another language. Cambridge: England; Cambridge University Press.

$>$ Nation, I.S.P. (2010). Learning Vocabulary in Another Language. Cambridge: Cambridge University Press

$>$ Nazir, F. (2017). A Collective Case Study on Vocabulary Instruction in Fifth Grade Classrooms.

$>$ Nassaji, H. (2004). The Relationship between Depth of Vocabulary Knowledge and L2 Learners' Lexical Inferencing Strategy Use and Success. Canadian Modern Language Review, 61(1), 107-135. https://doi.org/10.3138/cmlr.61.1.107

Noor, N.M. (2011). Reading habits and preferences of EFL post graduates: a case study. Indonesian Journal of Applied Linguistics, 1(1), 1-9.

$>$ Oljira, D. (2015). A Study on Problems of Vocabulary Teaching Techniques English Teachers Use in Holeta Primary Schools: Grade Seven in Focus. International Journal of Science and Research (IJSR) ISSN, 6(6), 2319-7064. https://doi.org/10.21275/15051705

$>$ Pathan, H. (2012). A longitudinal investigation of Pakistani university students' motivation for learning English, http://theses.gla.ac.uk/4534/1/2012PathanPhD.pdf

$>$ Rubén Chacón-Beltrán, et al. Insights into Non-Native Vocabulary Teaching and Learning. Bristol, Multilingual Matters, 2010.

$>$ Read, J. (2000). Assessing vocabulary. Cambridge: Cambridge University Press

$>$ Reynor, Ellen. (2015). Words Matter: Teaching Vocabulary to Struggling Readers.

$>$ Schmitt, N. (Ed.). (2010). Researching Vocabulary - A Vocabulary Research Manual | N. Schmitt | Palgrave Macmillan. Palgrave.com. https://www.palgrave.com/gp/book/9781403985354

$>$ Sedita, J. (2005). Effective vocabulary instruction. Insights on Learning Disabilities, 2(1), 33-45.

> Sivagnanam, Sutasini \& Yunus, Melor. (2020). Utilizing Social Media in Vocabulary Enhancement among Primary ESL Learners. Universal Journal of Educational Research. 8. 490-498. 10.13189/ujer.2020.080220.

$>$ Stahl, S. A. (2005). "Four problems with teaching word meanings (and what to do to make vocabulary an integral part of instruction)," in E. H. Hiebert and M. L. Kamil (eds.), Teaching and learning vocabulary: Bringing research to practice, Mahwah, NJ: Erlbaum.

$>$ Susan Hanson, Padua, J. F. M., \& Pacific Resources For Education And Learning (Prel. (2011). Teaching Vocabulary Explicitly. Effective Instructional Strategies Series. Editora: Pacific Resources For Education And Learning (Prel). 900 Fort Street Mall Suite, Honolulu, Hi 3-. Tel: 800-377-; Tel: 808-441-; Fax: 888512-; E-Mail: Askprel@Prel.org; Web Site: Http://Www.Prel.org -00-00. https://www.prel.org/wpcontent/uploads/2014/06/vocabulary_lo_res.pdf

$>$ Warsi, J. (2004). Conditions under which English is taught in Pakistan: an applied linguistic perspective. Citeseerx.Ist. Psu.Edu

https://citeseerx.ist.psu.edu/viewdoc/download?doi=10.1.1.562.9996\&rep=rep1\&type=pdf

$>$ Watkins, P. (2007). Learning to teach English: A practical introduction for new teachers. New Delhi: Viva Books Private Limited

$>$ Webb, S. (2007). The effects of synonymy on second-language vocabulary learning. Reading in a Foreign Language, 19(2). https://files.eric.ed.gov/fulltext/EJ777733.pdf

$>$ Wilkins, D.A. (1972) Linguistics in Language Teaching. Australia: Edward Arnold

$>$ Young-Davy, B. (2014). Explicit Vocabulary Instruction. ORTESOL Journal, 31, $26-32$. https://eric.ed.gov/?id=EJ1152527 
Table 1. What Is Involved in Knowing a Word

\begin{tabular}{|c|c|c|c|}
\hline Aspect & Component & $\begin{array}{l}\text { Receptive } \\
\text { knowledge }\end{array}$ & $\begin{array}{l}\text { Productive } \\
\text { knowledge }\end{array}$ \\
\hline \multirow[t]{3}{*}{ Form } & spoken & $\begin{array}{l}\text { What does the word } \\
\text { sound like? }\end{array}$ & $\begin{array}{l}\text { How is the word } \\
\text { pronounced? }\end{array}$ \\
\hline & written & $\begin{array}{l}\text { What does the word } \\
\text { look like? }\end{array}$ & $\begin{array}{l}\text { How is the word } \\
\text { written and spelled? }\end{array}$ \\
\hline & word parts & $\begin{array}{l}\text { What parts are } \\
\text { recognizable in this } \\
\text { word? }\end{array}$ & $\begin{array}{l}\text { What word parts are } \\
\text { needed to express the } \\
\text { meaning? }\end{array}$ \\
\hline \multirow[t]{3}{*}{ Meaning } & $\begin{array}{l}\text { form and } \\
\text { meaning }\end{array}$ & $\begin{array}{l}\text { What meaning does } \\
\text { this word form signal? }\end{array}$ & $\begin{array}{l}\text { What word form can } \\
\text { be used to express } \\
\text { this meaning? }\end{array}$ \\
\hline & $\begin{array}{l}\text { concepts and } \\
\text { referents }\end{array}$ & $\begin{array}{l}\text { What is included in } \\
\text { this concept? }\end{array}$ & $\begin{array}{l}\text { What items can the } \\
\text { concept refer to? }\end{array}$ \\
\hline & associations & $\begin{array}{l}\text { What other words } \\
\text { does this make people } \\
\text { think of? }\end{array}$ & $\begin{array}{l}\text { What other words } \\
\text { could people use } \\
\text { instead of this one? }\end{array}$ \\
\hline \multirow[t]{3}{*}{ Use } & $\begin{array}{l}\text { grammatical } \\
\text { functions }\end{array}$ & $\begin{array}{l}\text { In what patterns does } \\
\text { the word occur? }\end{array}$ & $\begin{array}{l}\text { In what patterns must } \\
\text { people use this word? }\end{array}$ \\
\hline & collocations & $\begin{array}{l}\text { What words or types } \\
\text { of words occur with } \\
\text { this one? }\end{array}$ & $\begin{array}{l}\text { What words or types } \\
\text { of words must people } \\
\text { use with this one? }\end{array}$ \\
\hline & $\begin{array}{l}\text { constraints } \\
\text { on use } \\
\text { (register, } \\
\text { frequency ....) }\end{array}$ & $\begin{array}{l}\text { Where, when, and } \\
\text { how often would } \\
\text { people expect to meet } \\
\text { this word? }\end{array}$ & $\begin{array}{l}\text { Where, when, and } \\
\text { how often can people } \\
\text { use this word? }\end{array}$ \\
\hline
\end{tabular}

Source: Adapted from Nation (2001, p. 27).

Figure 1. 


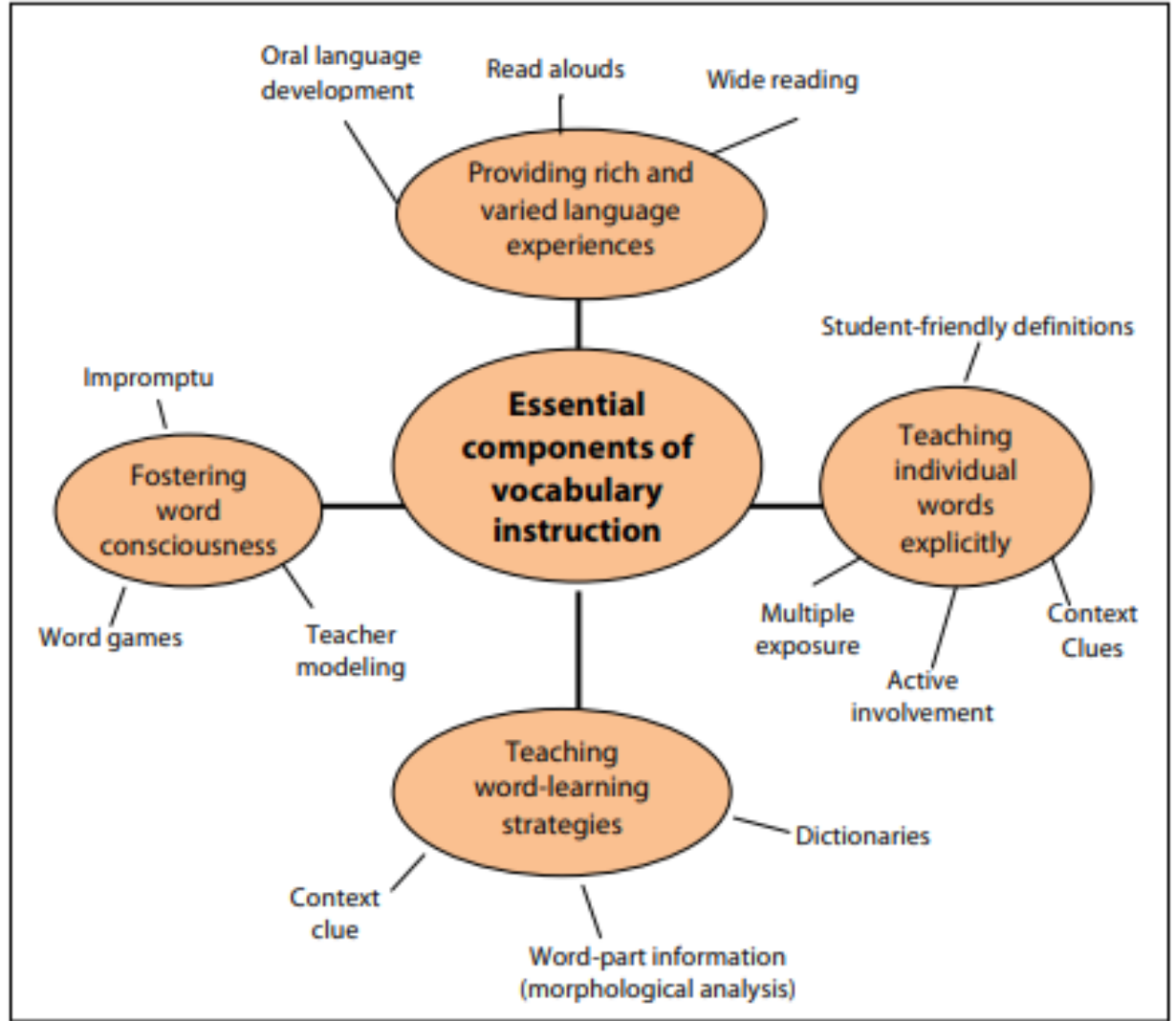

Figure 2 . 